Vol. 1 No. 1 September 2021, e-ISSN : 2807-8659 | p-ISSN : 2807-8829

\title{
MENINGKATKAN KEMAMPUAN SISWA MENYELESAIKAN PERMASALAHAN TRIGONOMETRI MELALUI PROLINK \\ SISWA KELAS XI IPA SMA NEGERI 1 TAJURHALANG \\ TAHUN PELAJARAN 2019/2020
}

\author{
MOHAMAD TAOFIK \\ SMA Negeri 1 Tajurhalang \\ Email : opikcamuhe@email.ac.id
}

\begin{abstract}
ABSTRAK
Untuk menghadapi era Revolusi Industri 4.0, siswa harus dibekali keterampilan berpikir tingkat tinggi (higher order thinking skills). Salah satu model pembelajaran yang berorientasi pada HOTS dan disarankan dalam implementasi Kurikulum 2013 adalah model pembelajaran berbasis masalah problem based learning (PBL) dengan metode Inkuiri. Tujuan penulisan praktik baik ini adalah untuk mendeskripsikan praktik baik penulis dalam menerapkan pembelajaran berorientasi higher order thiking skills (HOTS) pada model pembelajaran PBL dengan proses Inkuiri. Sasaran pelaksanaan best practice ini adalah siswa kelas XI semester 1 di SMANegeri 1 Tajurhalang Kabupaten Bogor sebanyak 216 orang siswa yang terbagi dalam 6 kelas. setelah melaksanakan pembelajaran matematika peminatan di kelas XI dalam pokok bahasan penjumlahan dan pengurangan sinus dan kosinus dengan model PBL, penulis menemukan bahwa proses dan hasil belajar siswa meningkat. Lebih bagus dibandingkan pembelajaran sebelumnya yaitu Xmin1 $=20$, Xmin2 $=43$; Xmaks1 $=100$, X Maks2 $=91 ; \bar{x} 1=$ $59,83, \bar{x} 2=74,75 ; \mathrm{Mo} 1=62, \mathrm{Mo} 2=64 ; \mathrm{S} 1=21,442, \mathrm{~S} 2=11,726$. Dengan nilai standar deviasi $\mathrm{S} 2<\mathrm{S} 1$ atau $11,726<21,442$, menunjukan bahwa pembelajaran menggunakan model PBL dengan proses Inkuiri lebih baik dibandingkan sebelumnya. Praktik pembelajaran PBL yang berhasil baik ini penulis simpulkan sebagai sebuah best practice (praktik baik) pembelajaran berorientasi HOTS dengan model PBL pada pokok bahasan jumlah dan selisih sinus dan kosinus. Proses pembelajaran yang dilakukan dengan menerapkan model pembelajaran PBL dengan proses inkuiri berlangsung aktif. Siswa menjadi lebih aktif merespon pertanyaan dari guru, termasuk mengajukan pertanyaan pada guru maupun temannya. Penerapan model pembelajaran PBL dan proses inkuiri ini juga meningkatkan kemampuan siswa dalam memecahkan masalah (problem solving). Setelah mengadakan penelitian ini didapat bahwa Permasalahan penjumlahan dan penguragan sinus dan kosinus yang melibatkan sudut $90^{\circ}$. ternyata siswa menemukan kesimpulan bahwa untuk sudut $90^{\circ}$ permasalahan tersebut tidak dapat diselesaikan karena menghasilkan cos $90^{\circ}$ yang bernilai nol.
\end{abstract}

Kata Kunci : PBL, Best Practice, Soal HOTS

\section{PENDAHULUAN}

Pembelajaran matematika peminatan kelas XI di SMA Negeri 1 Tajurhalang khususnya pada penjumlahan dan pengurangan sinus dan kosinus sesuai dengan tuntutan Kurikulum 2013, pendekatan pembelajaran yang mengintegrasikan beberapa kecakapan pada pelajaran matematika wajib di kelas $\mathrm{X}$ dalam pokok bahasan perbandingan trigonometri dan persamaan trigonometri pada mata pelajaran matematika peminatan kelas XI semester 1 sangat dibutuhkan, sehingga diharapkan setelah siswa mempelajari pokok bahasan penjumlahan dan pengurangan sinus dan kosinus siswa sudah dianggap lengkap memahami materi trigonometri untuk tingkat SMA. Karena pelajaran trigonometri di kelas XI pokok bahasan penjumlahan dan pengurangan sinus dan kosinus merupakan pokok bahasan yang sangat mendukung materi trigonometri lainnya yang akan dipelajari di kelas XII termasuk pokok bahasan Limit Trigonometri.

Dalam kegiatan pembelajaran Kurikulum 2013 yang penulis lakukan selama ini, penulis menggunakan buku siswa dan buku guru. Penulis meyakini bahwa buku tersebut sudah sesuai dan baik digunakan di kelas karena diterbitkan oleh Kementerian Pendidikan dan Kebudayaan. Tetapi dalam praktiknya, penulis mengalami beberapa kesulitan seperti materi dan tugas tidak 
sesuai dengan latar belakang siswa di SMA Negeri 1 Tajurhalang. Padahal menurut Isrok'atun Dan Rosmala (2019 : 2) bahwa kegiatan belajar mengajar memiliki beberapa aspek yang harus diperhatikan terkait kelancaran pelaksanaan. Beberapa aspek itu antara lain materi dan karakteristik siswa sehingga terjadi interaksi pembelajaran yang saling memengaruhisatu sama lain. Selain itu baik penulis maupun guru lainnya masih mengutamakan kemampuan siswa yang berfokus pada penguasaan pengetahuan yang lebih mementingkan hapalan, hal ini tidak sesuai dengan apa yang dikatakan Rusman (2018 : 134) bahwa belajar bukan hanya sekedar menghapal, melainkan suatu proses mental yang terjadi dalam diri seseorang. Begitu juga menurut Anderson dan Krathwolh yang dikemukakan oleh Rusmono (2017 : 8) bahwa dimensi pengetahuan dibagi menjadi empat tingkatan yaitu pengetahuan faktual, konseptual, prosedural dan meta-kognitif.

Dalam mencapai tujuan belajar salah satunya adalah ketersedian media pembelajaran, seperti yang dikemukakan oleh wati (2016 : 2) bahwa:

"Media dapat digunakan sebagai penyampai pesan untuk mencapai tujuan pembelajaran. Media merupakan suatu yang bersifat meyakinkan pesan dan dapat merangsang pikiran, perasaan, dan kemauan audiens atau siswa sehingga dapat mendorong terjadinya proses belajar pada diri siswa tersebut." tetapi kenyataannya guru jarang menggunakan media pembelajaran, dampaknya, suasana pembelajaran di kelas kaku dan anak-anak tampak tidak ceria, suasana belajar selalu itu-itu saja, Begitu juga proses berpikir siswa masih dalam level C1 (mengingat), memahami (C2), dan C3 (aplikasi), masih banyak sekali siswa dalam mengikuti belajar matematika menghabiskan waktu hanya untuk mencatat hasil yang sudah dikerjakan guru atau teman lainnya, tidak berusaha untuk mencari penyelesaian sendiri. Guru juga masih kurang melaksanakan pembelajaran yang berorientasi pada keterampilan berpikir tingkat tinggi (higher order thinking skills/ HOTS).

Untuk menghadapi era Revolusi Industri 4.0, siswa harus dibekali keterampilan berpikir tingkat tinggi (higher order thinking skills). Salah satu model pembelajaran yang berorientasi pada HOTS dan disarankan dalam implementasi Kurikulum 2013 adalah model pembelajaran berbasis masalah problem based learning (PBL) dengan metode Inkuiri. Seperti yang dikemukakan oleh Ibrahim dan Nur (2000 : 2) dalam Rusman (2018 : 241) bahwa Pembelajaran Berbasis Masalah merupakan salah satu pendekatan pembelajaran yang digunakan untuk merangsang berpikir tingkat tinggi siswa. PBL mengedepankan strategi pembelajaran menggunakan masalah dari dunia nyata (kontekstual) untuk belajar tentang cara berpikir kritis dan keterampilan pemecahan masalah, serta untuk memperoleh pengetahuan dan konsep esensial dari materi yang dipelajarinya. PBL membelajarkan siswa untuk berpikir secara kritis dan analitis, serta mencari dan menggunakan sumber pembelajaran yang sesuai untuk memecahkan masalah yang dihadapi. Inkuiri memiliki arti pertanyaan, atau pemeriksaan, penyelidikan. Inkuiri berarti suatu rangkaian kegiatan belajar yang melibatkan secara maksimal seluruh kemampuan siswa untuk mencari dan menyelidiki secara sistematis, kritis, logis, analitis, sehingga mereka dapat merumuskan sendiri penemuannya dengan penuh percaya diri. Hamdayama (2015 : 31) menjelaskan bahwa inkuiri artinya proses pembelajaran didasarkan pada pencarian dan penemuan melalui proses berpikir secara sistematis, begitu juga di SMA Negeri 1 Tajurhalang, setelah melaksanakan pembelajaran matematika peminatan di kelas XI dalam pokok bahasan penjumlahan dan pengurangan sinus dan kosinus dengan model PBL, penulis menemukan bahwa proses dan hasil belajar siswa meningkat. Lebih bagus dibandingkan pembelajaran sebelumnya. Praktik pembelajaran PBL yang berhasil baik ini penulis simpulkan sebagai sebuah best practice (praktik baik) pembelajaran berorientasi HOTS pada model PBL dengan proses Inkuiri pada pokok bahasan jumlah dan selisih sinus dan kosinus.

\section{METODE PENELITIAN}

Tujuan penulisan praktik baik ini adalah untuk mendeskripsikan praktik baik penulis dalam menerapkan pembelajaran berorientasi higher order thiking skills (HOTS) pada model 
pembelajaran PBL dengan proses Inkuiri. Sasaran pelaksanaan best practice ini adalah siswa kelas XI semester 1 di SMANegeri 1 Tajurhalang Kabupaten Bogor sebanyak 216 orang siswa yang terbagi dalam 6 kelas. Metode yang digunakan dalam Best Practice ini adalah metode kualitatif, yaitu memperhatikan atau mengamati perubahan baik sikap siswa maupun cara siswa mengikuti pelajaran serta perubahan nilai hasil test dengan cara membandingkan nilai sebelum dan nilai sesudah pembelajaran menggunakan model pembelajaran PBL dengan proses Inkuiri. Nilai-nilai tersebut adalah: Nilai terkecil dan nilai terbesar, rata-rata, median dan modus serta standar deviasi.

\section{HASIL DAN PEMBAHASAN}

Hasil yang dapat diilaporkan dari praktik baik ini diuraikan sebagai berikut.

1) Hasil analisis deskriptif data sebelum dan sesudah melakukan pembelajaran menggunakan model pembelajaran PBL dengan proses Inkuiri didapat data sebagai berikut:

Tabel 1. Analisis Deskriptif Data Sebelum dan Sesudah menggunakan Model PBL Dengan Proses Inkuiri

\begin{tabular}{|l|c|c|c|}
\hline \multicolumn{4}{|c|}{ Statistics } \\
\hline $\mathrm{N}$ & & $\begin{array}{c}\text { Test Pra } \\
\text { Eksperiment }\end{array}$ & $\begin{array}{c}\text { Test Setelah } \\
\text { Eksperiment }\end{array}$ \\
\hline & Valid & 36 & 36 \\
\hline Mean & & 59,83 & 74,75 \\
\hline Median & & 63,00 & 77,50 \\
\hline Mode & & 62 & $64^{\mathrm{a}}$ \\
\hline $\begin{array}{l}\text { Std. } \\
\text { Deviation }\end{array}$ & & 21,442 & 11,726 \\
\hline Skewness & & $-0,193$ & $-0,628$ \\
\hline $\begin{array}{l}\text { Std. Error of } \\
\text { Skewness }\end{array}$ & & 0,393 & 0,393 \\
\hline Kurtosis & & $-0,630$ & $-0,066$ \\
\hline $\begin{array}{l}\text { Std. Error of } \\
\text { Kurtosis }\end{array}$ & & 0,768 & 0,768 \\
\hline Minimum & & 20 & 43 \\
\hline Maximum & & 100 & 91 \\
\hline Sum & & 2154 & 2691 \\
\hline a. Multiple modes exist. The smallest value is shown \\
\hline
\end{tabular}

Deskripsi

Dari data pada tabel di atas menunjukan bahwa:

Nilai sebelum pembelajaran menggunakan model PBL dengan proses Inkuiri adalah:

Nilai terkecil : 20

Nilai Terbesar $\quad: 100$

Rata-rata $\quad: 59,83$

Median $\quad: 63,00$

Modus : 62

Standar Deviasi $\quad: 21,442$

Nilai sesudah pembelajaran menggunakan model PBL dengan proses Inkuiri adalah:

Nilai terkecil : 43

Nilai Terbesar $\quad: 91$

Rata-rata $\quad: 74,75$

Median : : 77,50 
Modus : 64

Standar Deviasi $\quad: 11,726$

Nilai-nilai di atas dapat penulis sajikan dalam histogram sebagai berikut:

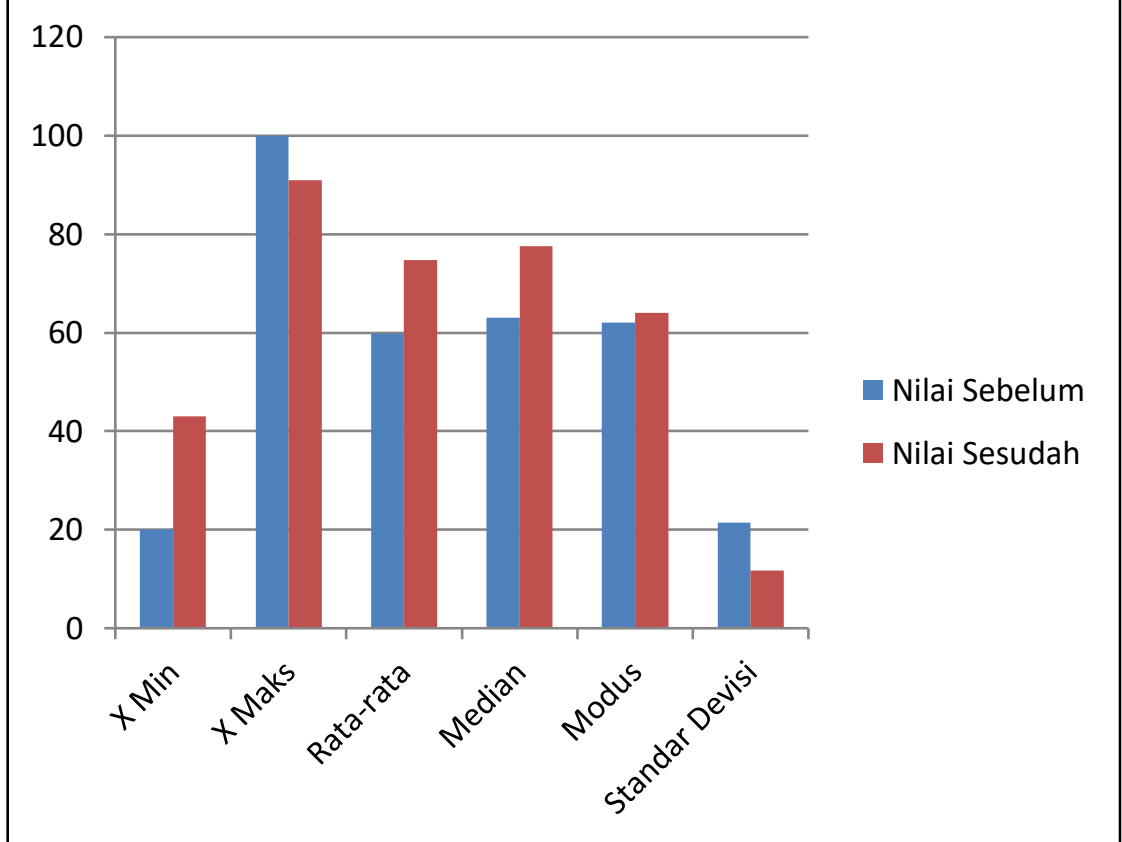

Gambar 1. Histogram Data Hasil Tes Sebelum dan Sesudah Pembelajaran Menggunakan Model PBL dengan Proses Inkuiri

Tampak bahwa pada gambar di atas bahwa:

Nilai terkecil atau nilai minimum $\quad$ : sesudah $>$ sebelum

Nilai terbesar atau nilai maksimum $\quad$ sesudah $<$ sebelum

Rata-rata

: sesudah $>$ sebelum

Median

: sesudah $>$ sebelum

Modus

: sesudah $>$ sebelum

Standar Deviasi

: sesudah $<$ sebelum

2) Proses pembelajaran yang dilakukan dengan menerapkan model pembelajaran PBL dengan proses inkuiri berlangsung aktif. Siswa menjadi lebih aktif merespon pertanyaan dari guru, termasuk mengajukan pertanyaan pada guru maupun temannya. Aktifitas pembelajaran yang dirancang sesuai sintak PBL megharuskan siswa aktif selama proses pembelajaran. Pembelajaran yang dilakukan dengan menerapkan model pembelajaran PBL dan proses inkuiri meningkatkan kemampuan siswa dalam melakukan transfer knowledge. Seperti pada Foto berikut ini: 


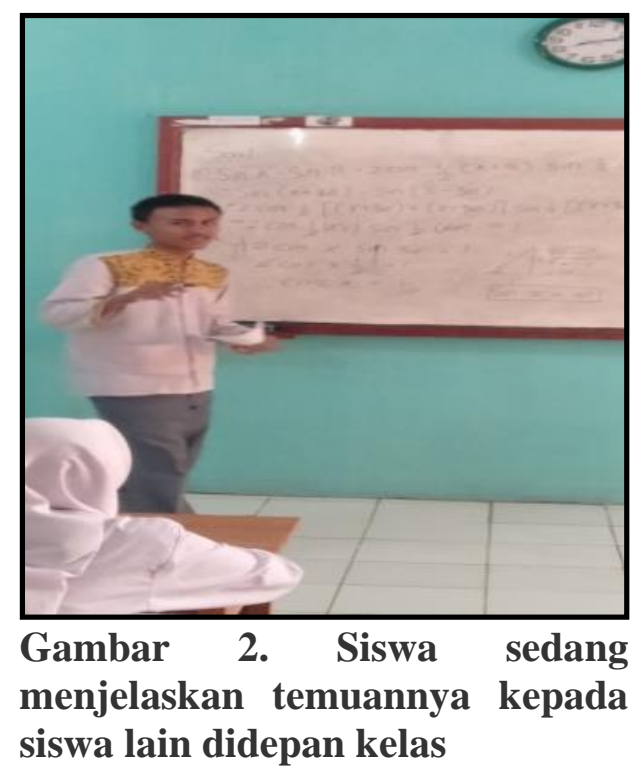

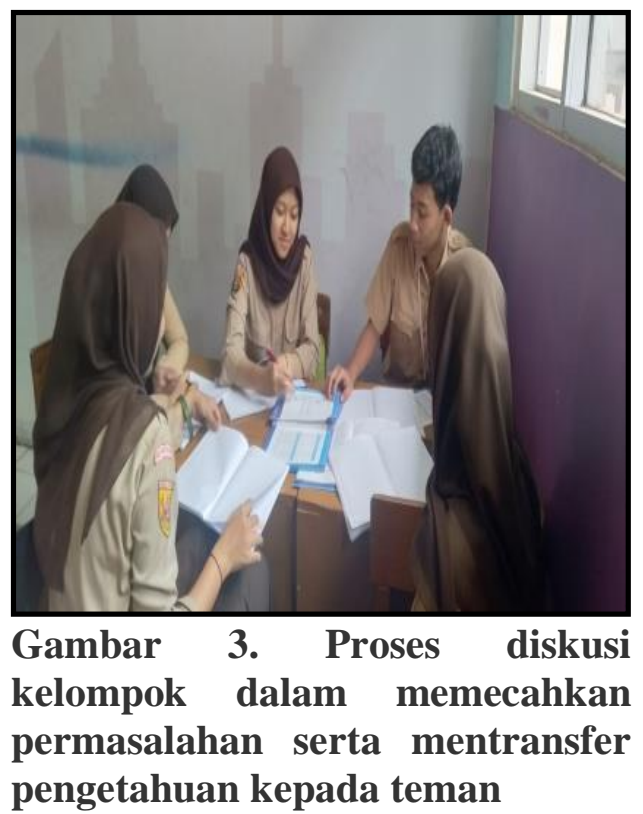

3) Setelah membaca, meringkas, dan mendiskusikan permasalahan yang diajukan guru, siswa tidak hanya memahami konsep penjumlahan sinus dan kosinus (pengetahuan konseptual) dan bagaimana membuat langkah-langkah penyelesaian yang benar (pengetahuan prosedural). Pemahaman ini menjadi dasar siswa dalam mempelajari persamaan yang melibatkan penjumlahan dan pengurangan sinus dan kosinus dalam rangka penguasaan pada materi trigonometri yang pada dasarnya merupakan bentuk pemahaman akhir siswa dalam memahami rumus-rumus trigonometri di SMA. Pemahaman ini dapat menjadi pengantar bagi siswa untuk memahami bagaimana menyelesaikan permasalahan trigonometri yang melibatkan penjumlahan dan pengurangan sinus dan kosinus pada materi di kelas berikutnya.

4) Penerapan model pembelajaran PBL meningkatkan kemampuan siswa untuk berpikir kritis. Hal ini dapat dilihat dari tingkat partisipasi siswa untuk bertanya dan menanggapi topik yang dibahas dalam pembelajaran. Dalam pembelajaran sebelumnya yang dilakukan penulis tanpa berorientasi HOTS suasana kelas cenderung sepi. Siswa cenderung bekerja sendiri-sendiri untuk berlomba menyelesaikan tugas yang diberikan guru. Fokus guru adalah bagaimana siswa dapat menyelesikan soal yang disajikan; kurang peduli pada proses berpikir siswa. Tak hanya itu, materi pembelajaran yang selama ini selalu disajikan dengan pola deduktif (diawali dengan ceramah teori tentang materi yang dipelajari, pemberian tugas, dan pembahasan), membuat siswa cenderung menghapalkan teori. Pengetahuan yang diperoleh siswa adalah apa yang diajarkan oleh guru. Berbeda kondisinya dengan praktik baik pembelajaran jumlah dan selisih sinus dan kosinus berorientasi HOTS dengan menerapkan PBL dan proses inkuiri ini. Dalam pembelajaran ini pemahaman siswa tentang konsep trigonometri, tentang penjumlahan dan pengurangan sinus dan kosinus dibangun oleh siswa melalui pengamatan dan diskusi yang menuntut kemampuan siswa untuk berpikir kritis.

5) Penerapan model pembelajaran PBL dan proses inkuiri ini juga meningkatkan kemampuan siswa dalam memecahkan masalah (problem solving). PBL yang diterapkan dengan menyajikan permasalahan kontekstual mampu mendorong siswa merumuskan pemecahan masalah. Sebelum menerapkan PBL dan Inkuiri, penulis melaksanakan pembelajaran sesuai dengan buku guru dan buku siswa. Meskipun permasalahan yang disajikan dalam buku teks kadang kala kurang sesuai dengan kehidupan sehari-hari siswa, tetap saja penulis gunakan. Dengan menerapkan PBL dan inkuiri, siswa tak hanya belajar dari buku teks saja, tetapi juga dari permasalahan yang siswa ajukan sendiri, serta diberi kesempatan terbuka untuk mencari informasi, materi dari sumber lainnya, seperti pada foto berikut: 

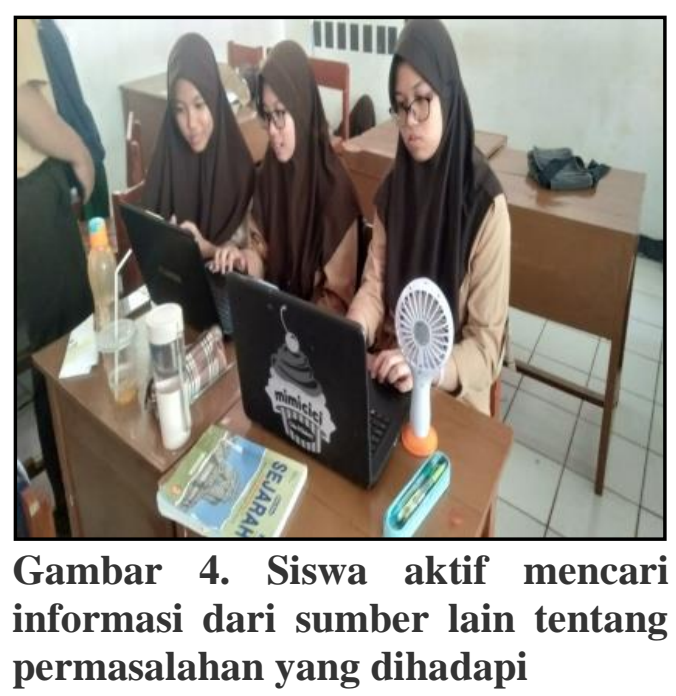

6) Pada kegiatan diskusi kelompok dan mencari informasi, hal yang sangat mencengangkan adalah ketika peserta didik mendapatkan sebuah permasalahan penjumlahan dan penguragan sinus dan kosinus yang melibatkan sudut $90^{\circ}$. Ternyata selama penulis mengajar hal ini belum pernah muncul yaitu permasalahan:

$\operatorname{Sin}(\mathrm{x}+90)^{\circ}+\sin (\mathrm{x}-90)^{\circ}=\mathrm{k}$

$\operatorname{Cos}(\mathrm{x}+90)^{\circ}+\cos (\mathrm{x}-90)^{\circ}=\mathrm{k}$

Dari permasalahan tersebut ternyata siswa menemukan kesimpulan bahwa untuk sudut $90^{\circ}$ permasalahan tersebut tidak dapat diselesaikan karena menghasilkan cos $90^{\circ}$ yang bernilai nol.

a. $\operatorname{Sin}(\mathrm{x}+90)^{\circ}+\sin (\mathrm{x}-90)^{\circ}=\mathrm{k}$

$\equiv 2 \sin \mathrm{x} \cos 90^{\circ}=\mathrm{k}$

$\equiv 2 \sin \mathrm{x} \cdot 0=\mathrm{k}$

$0=\mathrm{k}$ hal ini tidak mungkin, untuk $\mathrm{k}$ sebuah bilangan, kecuali nol itu sendiri

b. $\cos (\mathrm{x}+90)^{\circ}+\cos (\mathrm{x}-90)^{\circ}=$

$\equiv 2 \cos \mathrm{x} \cos 90^{\circ}=\mathrm{k}$

$\equiv 2 \cos \mathrm{x} .0=\mathrm{k}$

$0=\mathrm{k}$ hal ini tidak mungkin untuk $\mathrm{k}$ sebuah bilangan. kecuali nol itu sendiri

\section{Pembahasan}

1) Dilihat dari nilai-nilai hasil tes sebelum dan sesudah pembelajaran menggunakan model PBL dengan proses Inkuiri bahwa proses dan hasil belajar siswa meningkat. Lebih bagus dibandingkan pembelajaran sebelumnya yaitu Xmin $1=20, X \min 2=43$; Xmaks1 $=100, X$ Maks2 $=91 ; \bar{x} 1=59,83, \bar{x} 2=74,75 ; \mathrm{Mo} 1=62, \mathrm{Mo} 2=64 ; \mathrm{S} 1=21,442, \mathrm{~S} 2=11,726$. Dengan nilai standar deviasi S2 $<$ S1 atau 11,726<21,442, menunjukan bahwa pembelajaran sesudah menggunakan model PBL dengan proses Inkuiri lebih baik dibandingkan pembelajaran sebelumnya.

2) Proses pembelajaran yang dilakukan dengan menerapkan model pembelajaran PBL dapat meningkatkan aktifitas siswa dalam belajar serta meningkatkan kemampuan siswa dalam mentransfer pengetahuan atau transfer knowledge.

3) Setelah mengikuti pembelajaran menggunakan model PBL dengan proses inkuiri, siswa tidak hanya memahami konsep dan langkah-langkah penyelesaian masalah penjumlahan sinus dan kosinus, tetapi menjadi dasar pengetahuan untuk mempelajari materi trigonometri yang lainnya yang melibatkan penjumlahan sinus dan kosinus

4) Penerapan model pembelajaran PBL meningkatkan kemampuan siswa untuk berpikir kritis.

5) Penerapan model pembelajaran PBL dan proses inkuiri ini juga meningkatkan kemampuan siswa dalam memecahkan masalah (problem solving). Dengan menerapkan PBL dan inkuiri, 
siswa tak hanya belajar dari buku teks saja, tetapi juga dari permasalahan yang siswa ajukan sendiri, serta diberi kesempatan terbuka untuk mencari informasi, materi dari sumber lainnya.

6) Penerapan model pembelajaran PBL dan proses inkuiri peserta didik mendapatkan sebuah permasalahan penjumlahan dan penguragan sinus dan kosinus yang melibatkan sudut $90^{\circ}$. sebagai suatu hal yang tidak mungkin atau tidak mempunyai penyelesaian.

\section{Masalah yang Dihadapi}

Masalah yang dihadapi siswa adalah belum trampilnya siswa menyelesaikan masalah yang berhubungan dengan jumlah dan selisih sinus dan kosinus dalam bentuk $\pi$, sehingga rata-rata siswa hanya dapat menyelesaikan soal separuh jalan saja atau memakan waktu yang lebih lama.missalnya:

$\operatorname{Sin}\left(x-\frac{1}{3} \pi\right)+\operatorname{Sin}\left(x+\frac{1}{4} \pi\right)$

$=2 \operatorname{Sin} \frac{1}{2}\left[\left(\mathrm{x}-\frac{1}{3} \pi\right)+\left(\mathrm{x}+\frac{1}{4} \pi\right)\right] \operatorname{Cos} \frac{1}{2}\left[\left(\mathrm{x}-\frac{1}{3} \pi\right)-\left(\mathrm{x}+\frac{1}{4} \pi\right)\right]$

$=2 \operatorname{Sin} \frac{1}{2}\left[2 \mathrm{x}+\left(-\frac{1}{3}+\frac{1}{4}\right) \pi\right] \operatorname{Cos} \frac{1}{2}\left[\left(-\frac{1}{3}-\frac{1}{4}\right) \pi\right] \ldots$. Pada tahap inilah saat siswa harus menjumlahkan atau mengurangkan pecahannya, dan siswa masih selalu bertanya pada guru berapa hasilnya.

\section{Cara Mengatasi Masalah}

Agar siswa yakin bahwa pembelajaran jumlah sinus dan kosinus dengan PBL melalui proses inkuiri, dapat membantu mereka lebih menguasai materi pembelajaran, guru memberi penjelasan dan bimbingan terus menerus terutama dalam menjumlahkan atau mengurangkan sudut dalam bentuk $\pi$, yang umumnya bentuk pecahan. Dan disinilah tampak manfaat belajar berorientasi pada keterampilan berpikir tingkat tinggi (higher order thinking skills (HOTS). Pemahaman dan kesadaran akan pentingnya HOTS akan membuat siswa termotivasi untuk mengikuti pembelajaran.

\section{KESIMPULAN}

Berdasarkan uraian di atas dapat ditarik kesimpulan sebagai berikut.

1) Pembelajaran jumlah dan selisih sinus dan kosinus dengan model pembelajaran PBL melalui proses inkuiri layak dijadikan praktik baik pembeljaran berorientasi HOTS karena dapat meningkatkan kemampuan siswa dalam melakukan transfer pengetahuan, berpikir kritis, dan pemecahan masalah.

2) Dengan penyusunan rencana pelaksanaan pembelajaran (RPP) secara sistematis dan cermat, pembelajaran jumlah dan selisih sinus dan kosinus dengan model pembelajaran PBL melalui proses inkuiri yang dilaksanakan tidak sekadar berorientasi HOTS, tetapi juga mengintegrasikan PPK, literasi, dan kecakapan abad 21.

\section{DAFTAR PUSTAKA}

Hamdayama Jumanta. (2014). Model-model Pembelajaran Kreatif dan Berkarakter. Bogor: Galhia Indonesia

Isrok'atun, Rosmala Amelia. (2019). Model-model Pembelajaran Matematika. Jakarta: PT. Bumi Aksara.

Permendikbud Nomor 22 Tahun 2016 tentang Standar Proses

Rusman. (2018). Model-model Pembelajaran. Jakarta : PT. Raja Grafindo Persada.

Rusmono. (2017). Strategi Pembelajaran dengan Problem Based Learning. Bogor: Galhia Indonesia.

Wati. Ega Rima. (2016). Ragam media Pembelajaran. Jakarta: Kata pena. 